Article

\title{
The Viability of Energy Auditing in Countries with Low Energy Cost: A Case Study of a Residential Building in Cold Climates
}

\author{
Ebrahim Solgi ${ }^{1, *(1)}$, Zahra Hamedani ${ }^{1}$, Shahab Sherafat ${ }^{2}$, Ruwan Fernando ${ }^{1}$ and \\ Farshid Aram ${ }^{3}$ (1) \\ 1 School of Engineering and Built Environment, Griffith University, Gold Coast 4222, Australia \\ 2 Department of Architecture and Energy, University of Art, Tehran 11369, Iran \\ 3 Department of Urban and Regional Planning, Polytechnic University of Madrid-UPM, 28040 Madrid, Spain \\ * Correspondence: ebrahim.solgi@griffithuni.edu.au
}

Received: 29 June 2019; Accepted: 5 August 2019; Published: 8 August 2019

check for updates

\begin{abstract}
The continuing importance of energy conservation in the building sector has drawn major attention to energy audits of existing buildings in different climates. In this paper, the energy conservation potential of a residential building located in Iran's cold climate was investigated through an analysis of its actual energy consumption and through computer simulation. The building base-load was determined using a linear regression method based on existing energy bills, and was used to validate the computer simulation of its energy usage. The impact of typical energy saving solutions was evaluated for three cost refurbishment scenarios: low, medium and high. The results show that the existing construction and envelope materials fail to meet the national standards of Iran, but insulating the envelope was found to be a more cost-effective measure than modifying the windows. The results also demonstrate that although the use of energy-saving solutions has a significant impact on energy consumption, even the most economic solutions investigated will have a payback period longer than one decade. Thus, with current energy prices the reviewed energy conservation strategies are not economically justified in Iran from the consumer perspective, as investment in the methods considered typical in other parts of the world will not show a return for at least a half-century.
\end{abstract}

Keywords: energy audit; energy-efficient design; residential buildings; building refurbishment; energy efficiency

\section{Introduction}

Carbon dioxide $\left(\mathrm{CO}_{2}\right)$ emissions produced as a result of burning fossil fuels to provide energy for buildings, significantly contribute to global warming and climate change [1-3]. Furthermore, the built environment is also considered a major energy consumer, as approximately half of the world's energy use is associated with the building sector, predominantly in providing occupants with comfortable environmental conditioning (through heating, cooling and mechanical ventilation) [4,5]. With ever rising worldwide energy demand, management and conservation methods have risen in critical importance. It is recognized that reducing energy consumption results in positive environmental and economic returns and due to the economic aspects of energy usage patterns, many individuals and businesses reduce their operating costs by minimizing energy usage [6].

The majority of green building codes and regulations focus on new buildings. The number of green buildings increases $0.5-2 \%$ annually depending on their prevailing socioeconomic surroundings $[7,8]$. This low rate reveals that effective design of new buildings will not address the overall energy reduction 
challenge and $\mathrm{CO}_{2}$ emissions will remain at an unacceptably high level. Therefore, refurbishment and energy auditing for existing buildings are required to meet the targets for controlling greenhouse emissions [9]. Energy auditing has a lower cost and is technically a more mature option than utilizing advanced and costly means of providing renewable energy since it monitors and often controls energy demand [10]. An energy cost saving of $5-15 \%$ is usually achieved quickly with little to no capital investment or aggressive energy management [11].

Energy audits include energy conservation programs which encompass consumption patterns and the identification of specific energy saving measures [12]. That is, an energy audit is a systematic procedure to gain adequate knowledge of existing energy consumption profiles and detect operating problems, improve occupant comfort, identify and quantify cost-effective energy savings opportunities, and report the findings [13-15]. At the end of the energy audit, the correct strategy for improvement of the energy use of the building is proposed and will factor-in the complexity of the building, as well as the client's requirements along with their budget and time constraints. The commitment to different resources also needs to be considered with the ROI (Return on Investment) as the activities undertaken in an audit are usually recuperated from the savings generated within an arbitrary period of time [16]. The main goal of these strategies is to identify and develop modifications to reduce energy consumption, manage costs, and lower environmental impact [17].

Regarding the different levels of depth, three main (operational) levels of analysis have been determined in most of the literature as typified in ASHRAE's (American Association of Heating, Refrigerating and Air Conditioning Engineers) guidelines for energy audit [18-21]:

- a walk-through audit, a simple on-site visit to the building during which areas can be identified for simple and cost-effective actions, which can result in immediate operating-cost savings;

- an energy survey and analysis, taken from field measurements and analysis of the operating costs, which provides a detailed energy analysis for the energy systems of the building; and

- a detailed energy audit or simulation audit, which provides a detailed analysis of large capital investment required to make modifications to current systems; at this level, the auditor evaluates potential energy conservation opportunities (ECOs), such as adding double-pane windows, adding insulation, insulated doors or window shading and changing to higher efficiency air conditioners and water heaters [22], by means of energy modelling and simulation software to investigate the ROI for different solutions.

All energy audit levels result in a list of energy conservation opportunities (ECOs) which can be implemented according to the pre-determined objectives [16]. The above-mentioned levels have been used by many researchers for auditing existing buildings, who found that the building's performance can be considerably improved [23-25]. Li [26] conducted research on the energy performance of 19 government offices in Hong Kong and derived an average Energy Use Index based on unit floor area based on energy consumption data over the previous three years. After carrying out an energy audit for the case studies, energy management opportunities were identified and operational practices to improve energy performance were proposed. Iqbal et al. [27] carried out research where several energy conservation measures for office buildings were analyzed in the context of a hot and humid climate. In this research, a reduction of $36 \%$ of annual energy usage was expected from implementing energy management measures.

Escrivá et al. [28] modeled the profile of the daily cooling load of a group of air-conditioning systems in a university building. The model was used to analyze the control of energy usage in existing and proposed buildings. Subsequently, a validation study was carried out for a single zone at the university through measurements from an energy management and control system. Mills et al. [29] investigated the operation of the system in more than 130 newly retrofitted large office buildings. It was found that enhancing the operation efficiency saved $20 \%$ of energy with ROI time ranging from several months to one to two years in most cases. Philip et al. [30] investigated energy use by mechanical ventilation and air-conditioning (MVAC) systems in a typical commercial building. Energy auditing 
and further analysis provided a total of 20 energy-saving measures for possible use in local commercial buildings, thus assisting engineers in designing energy-efficient commercial buildings or procreating new concepts for MVAC systems improvement.

Ruiz et al. [31] addressed a multi-objective optimization model to minimize energy use in buildings in a cost-effective way, while at the same time retaining comfort standards for the building occupants. This optimization algorithm considers a set of retrofit actions including windows, roof insulation material, external wall insulation material, and installation of a solar collector. Afterwards, the feasibility of the proposed multi-objective model in a real-world situation was tested. Ehsan et al. [32] investigated multiple refurbishment scenarios including upgrades for the roof, wall, and glazing thermal properties on a residential building in Portugal. A MATLAB-based multi-objective optimization model was used to evaluate various refurbishment configurations. This research demonstrated that a proper choice of strategy can lead to substantial improvements in energy savings with moderate investment in refurbishment costs. However, the results also showed that some inappropriate strategies which are high-tech as well as high-cost, can be less financially effective. Zhu [33] utilized computer simulation technology to assess different energy conservation alternatives and to provide facility managers with reliable and feasible solutions, and showed remarkable energy savings as a result of using suggested energy management measures. Ascione et al. [34] used EnergyPlus software to explore the effect of implementing phase change materials (PCMs) in an existing building. It was found that in Mediterranean climates through adding PCMs into the inner side of the exterior envelopes, the energy demand reduced by augmenting PCM thicknesses.

At the present time in Iran, designers are motivated to utilize several energy-efficient techniques in their designs, which include night ventilation [35-39], earth-to-air heat exchanger systems [40], and double skin facades [41]. However, auditing is frequently undervalued in practice and limited research has been conducted in connection with energy auditing of residential buildings. This study attempts to provide an overview of the energy auditing potentials of residential buildings in the cold climate region of Iran. For this purpose, the data related to a typical building in this cold climate has been analyzed and used in EnergyPlus software (version 7.5, University of Illinois, Champaign, IL, USA), and then after validation, three categories of low-cost, medium-cost and high-cost scenarios have been shown to compare the initial investment and payback periods.

\section{Building Specifications}

\subsection{Case Study}

The studied building was a one-story residential unit typical of the cold climate of western Iran [42]. The openings of this building were restricted to its northern and southern sides. The plan and elevation of this building are illustrated in Figure 1. Constructed in 2001, this $124 \mathrm{~m}^{2}$ residential unit consisted of a $48 \mathrm{~m}^{2}$ living room, two $14 \mathrm{~m}^{2}$ and $16 \mathrm{~m}^{2}$ bedrooms, a $13 \mathrm{~m}^{2}$ kitchen, a $3.25 \mathrm{~m}^{2}$ restroom, a $4 \mathrm{~m}^{2}$ bathroom, and a $4 \mathrm{~m}^{2}$ storage room. The building housed a family of six. Natural light was provided through windows (on the northern and southern faces) with a total glazed area of $18 \mathrm{~m}^{2}$. Heat and hot water were provided by a central heating system with a maximum output of $29.8 \mathrm{~kW}$ and an efficiency of $75 \%$. Cooling was performed by a water cooler with a nominal aeration capacity of $4250 \mathrm{~m}^{3} / \mathrm{h}$ and an efficiency of $80 \%$. All windows were single-glazed steel-framed with a combined thermal conductivity of $5.8 \mathrm{~W} / \mathrm{m}^{2} \mathrm{~K}$. Most of the lamps used in the building were low energy types $(20 \mathrm{~W})$. 

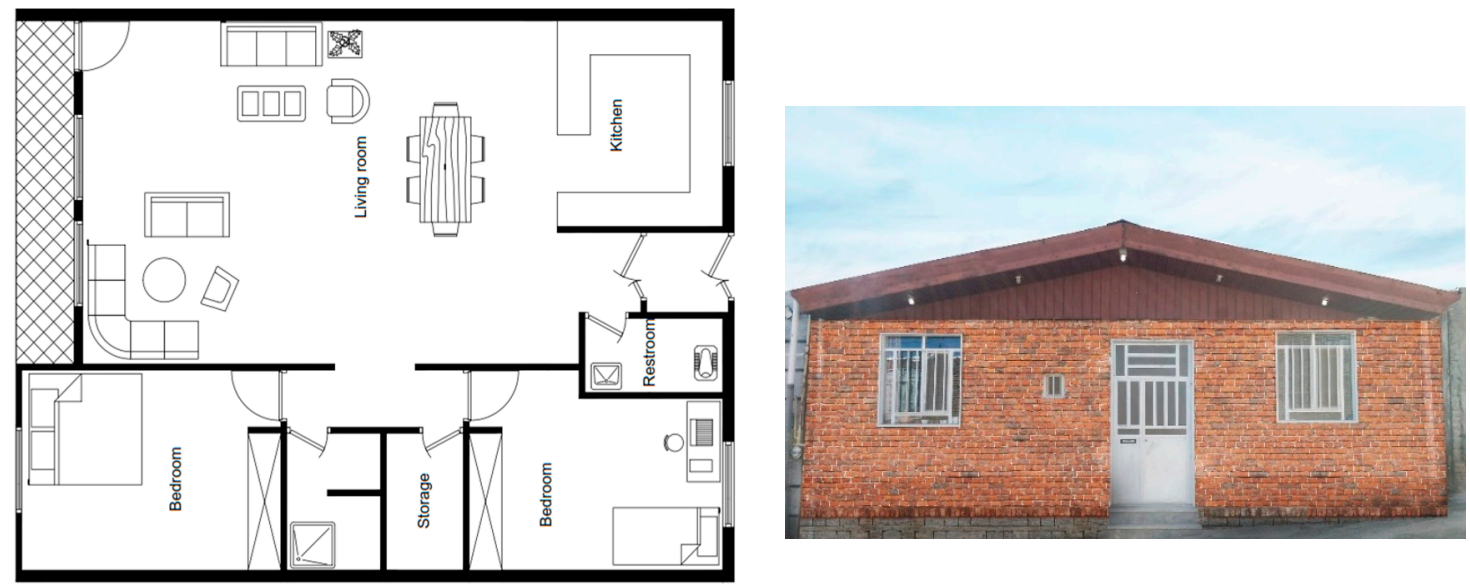

Figure 1. Case study plan and elevation.

\subsection{Location and Climate Specifications}

The city of Nahavand is located in the cool climate of western Iran at $48^{\circ} 22^{\prime} \mathrm{E}$ and $34^{\circ} 11^{\prime} \mathrm{N}$, at an elevation of $1725 \mathrm{~m}$ above sea level. The 10-year mean climate data of this city is provided in Table 1 [43]. Based on the Köppen and Geiger climate classification this city is located in cold climates [44]. In general, buildings in this city require heating from early November to middle April and require cooling from early May to early November. This city has annual heating degree days (HDD) and cooling degree days (CDD) of 2476.11 and 477, respectively, indicating the existence of both heating and cooling loads; however, although the former load is about four times greater than the latter.

Table 1. Average monthly weather data of Nahavand (1952-2010) [43].

\begin{tabular}{|c|c|c|c|c|c|c|c|c|c|c|c|c|}
\hline $\begin{array}{l}\text { Monthly } \\
\text { Averages }\end{array}$ & January & February & March & April & May & June & July & August & September & October & November & December \\
\hline $\begin{array}{l}\text { Temperature } \\
\left({ }^{\circ} \mathrm{C}\right)\end{array}$ & 0.2 & 0.1 & 6.7 & 14.4 & 19.1 & 23.7 & 27.5 & 26.6 & 21.3 & 13.4 & 6.8 & 2.2 \\
\hline $\begin{array}{l}\text { Minimum } \\
\text { temperature } \\
\left({ }^{\circ} \mathrm{C}\right)\end{array}$ & -17.8 & -16.8 & -5.2 & 2.4 & 4.4 & 8.0 & 13.0 & 10.2 & 7.4 & 1.0 & -3.0 & -9.2 \\
\hline $\begin{array}{l}\text { Maximum } \\
\text { temperature } \\
\left({ }^{\circ} \mathrm{C}\right)\end{array}$ & 15.2 & 13.4 & 19.2 & 25.6 & 31.0 & 37.5 & 37.6 & 36.0 & 33.8 & 24.4 & 18.8 & 13.2 \\
\hline $\begin{array}{c}\text { Relative } \\
\text { humidity (\%) }\end{array}$ & 71 & 67 & 47 & 42 & 31 & 26 & 24 & 25 & 27 & 49 & 70 & 78 \\
\hline $\operatorname{HDD}\left(18^{\circ} \mathrm{C}\right)$ & 541.96 & 446.5 & 393.52 & 188.0 & 67.8 & 2.57 & 0 & 0 & 6.06 & 116.5 & 290.61 & 438 \\
\hline $\operatorname{CDD}\left(25^{\circ} \mathrm{C}\right)$ & 0 & 0 & 0 & 0 & 1.2 & 45.6 & 151.7 & 138.3 & 14.3 & 0 & 0 & 0 \\
\hline
\end{tabular}

\subsection{Building Architecture}

The reference heat transfer coefficient of the building was calculated based on the building envelope specifications provided in Tables 2 and 3 . The reference heat transfer coefficient $(\hat{\mathrm{H}})$ expressed in $(\mathrm{W} / \mathrm{K})$ equals the maximum allowable steady-state heat transfer through the building envelope per $1{ }^{\circ} \mathrm{C}$ temperature difference between the indoor and outdoor air. The reference heat transfer coefficient calculations must take account of heat transfer through the roof, walls, doors and windows, and the floor in contact with either air or soil. These barriers may be adjacent to the outdoor space, uncontrolled spaces, or soil. To determine the reference heat transfer coefficient of a building, it is necessary to obtain the specifications of each component of the building envelope (which include the total net area of the walls, roof, the floor adjacent to air, doors, windows, barriers adjacent to uncontrolled spaces, and the floor adjacent to soil) according to the internal dimensions of the building. The reference heat transfer coefficient of the building was calculated using the following equation [45]:

$$
\hat{\mathrm{H}}=(\mathrm{AW} \times \hat{\mathrm{U} W})+(\mathrm{AR} \times \hat{\mathrm{UR}})+(\mathrm{AF} \times \hat{\mathrm{U} F})+(\mathrm{P} \times \hat{\mathrm{UP}})+(\mathrm{AG} \times \hat{\mathrm{U} G})+(\mathrm{AD} \times \hat{\mathrm{U} D})+(\mathrm{AWB} \times \hat{\mathrm{U} W B})
$$


Table 2. Dimensional specifications of the building envelope.

\begin{tabular}{|c|c|c|c|c|c|c|}
\hline Building Element & Position & $\begin{array}{c}\text { Total } \\
\text { Area }\left(\mathrm{m}^{2}\right)\end{array}$ & $\begin{array}{l}\text { Window } \\
\text { Area }\left(\mathrm{m}^{2}\right)\end{array}$ & $\begin{array}{c}\text { Door } \\
\text { Area }\left(\mathrm{m}^{2}\right)\end{array}$ & $\begin{array}{l}\text { Net Area } \\
\left(\mathrm{m}^{2}\right)\end{array}$ & $\begin{array}{l}\text { Total Net } \\
\text { Area }\left(\mathrm{m}^{2}\right)\end{array}$ \\
\hline \multirow{2}{*}{$\begin{array}{c}\text { Walls adjacent to } \\
\text { outdoors }\end{array}$} & Northern side & 30 & 3.92 & 2.88 & 23.2 & \multirow{2}{*}{44.62} \\
\hline & Southern side & 30 & 7.04 & 1.54 & 21.42 & \\
\hline \multirow{2}{*}{$\begin{array}{l}\text { Barrier adjacent to } \\
\text { controlled space }\end{array}$} & Eastern side & 39 & - & - & 39 & \multirow{2}{*}{74.85} \\
\hline & Western side & 35.85 & - & - & 35.85 & \\
\hline \multirow{2}{*}{ Floor } & $\begin{array}{l}\text { Adjacent to the } \\
\text { outdoors }\end{array}$ & 50.84 & - & - & 50.84 & \multirow{2}{*}{61.84} \\
\hline & $\begin{array}{c}\text { Adjacent to } \\
\text { uncontrolled spaces }\end{array}$ & 11 & - & - & 11 & \\
\hline $\begin{array}{l}\text { Barrier adjacent to } \\
\text { uncontrolled spaces }\end{array}$ & Ceiling & 124 & - & - & 124 & 123 \\
\hline Outer roof & Top face & 157 & - & - & 157 & 157 \\
\hline
\end{tabular}

Table 3. Specifications of the building elements.

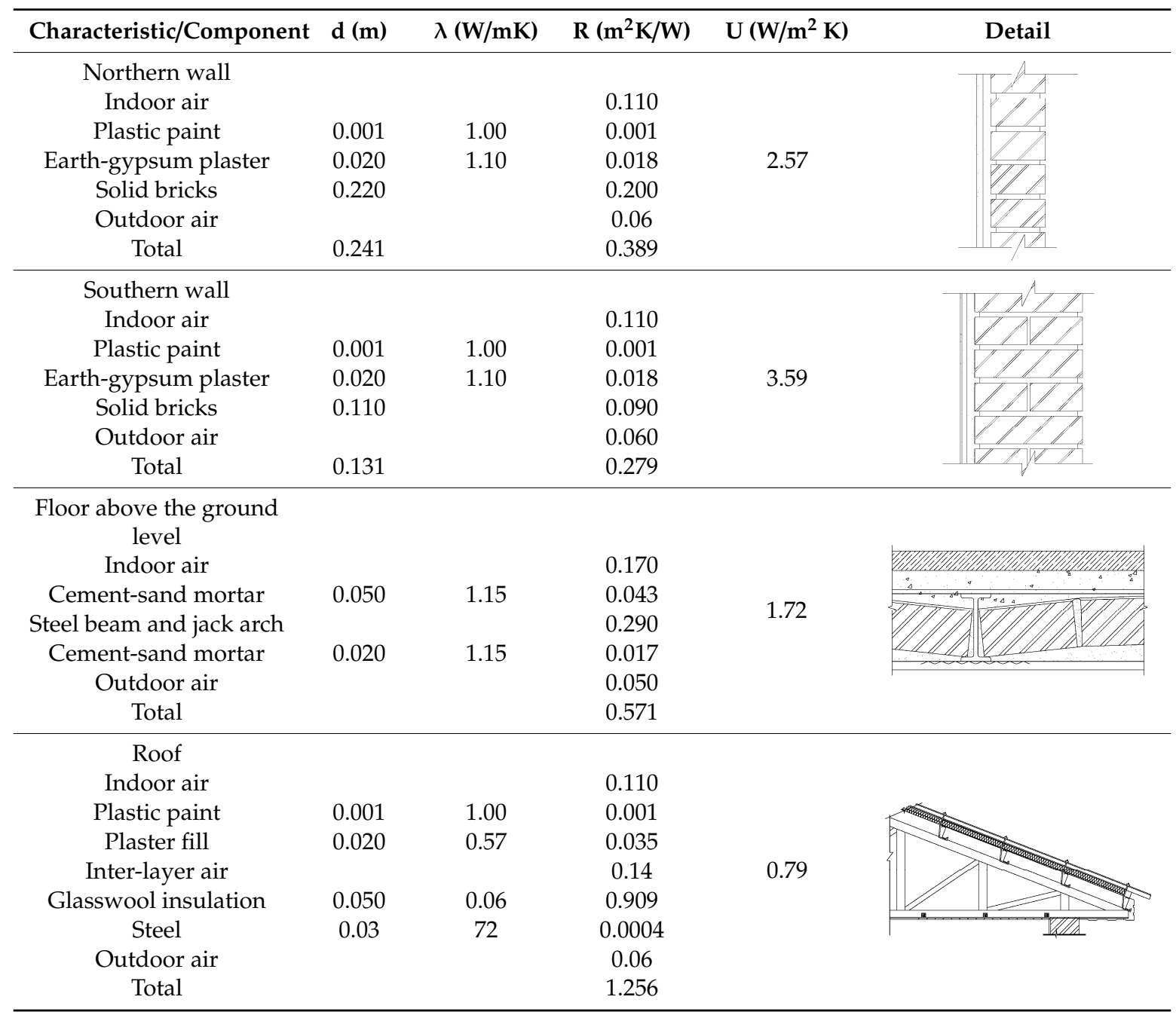

Currently, the walls and envelope of the studied building lack proper insulation and its windows are single-glazed. Therefore, using Equation (1), the heat transfer coefficient of the building $(\hat{\mathrm{H}})$ with thermal bridges included was calculated as being $410.94 \mathrm{~W} / \mathrm{K}$. This value exceeds the limit specified in current Iranian building regulations $(315.61 \mathrm{~W} / \mathrm{Km})$. Thus, the building envelope in its present 
condition would not comply with the standards specified in No. 19 of the Iranian National Building Code [45].

\section{Building Energy Consumption}

There are two general approaches to energy analysis [46]. The first approach, which is known as the forward approach, makes use of the physical specifications of the building (location, geometry, material and construction details, type of heating, ventilation, and air-conditioning (HVAC) system, and building use) to estimate its heating and cooling load. The second approach known as the inverse approach (Figure 2), suggests that the available climate, efficiency, and energy use data can be used to develop an energy analysis model capable of producing representative building parameters such as the building load coefficient (BLC), the building base-load, or the building time constant. In the majority of existing inverse models, the building representative parameters, or parameters such as BLC and heating system efficiency (which represents a part of the system) are estimated by applying regression analysis techniques such as the variable-base degree-day method [47], the connectionist method [48], or the change-point method [49] on the measured data.

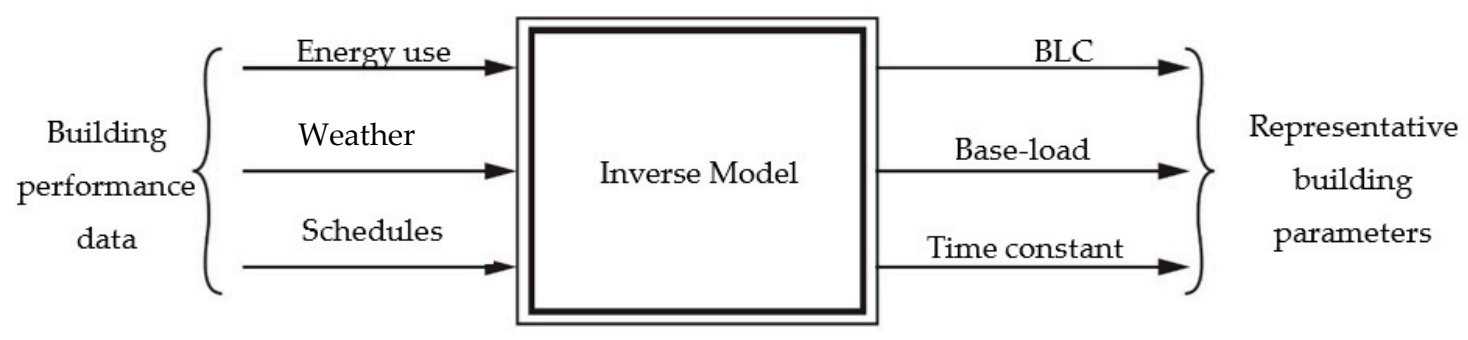

Figure 2. Basic approach of a typical inverse energy analysis model [46].

In the linear regression, we assume that the linear relation between a dependent quantity and an independent quantity can be expressed as [46]:

$$
\mathrm{y}=\mathrm{mx}+\mathrm{c}
$$

where $y$ denotes the dependent variable, $x$ denotes the independent variable, and $\mathrm{m}$ and $\mathrm{c}$ denote the slope and y-intercept of the regression line, respectively.

Assuming the monthly degree days as the independent variable and the monthly fuel consumption as the dependent variable, the slope of their regression line will be the building load coefficient (BLC) and the intercept will be the monthly base-fuel consumption. On this basis, the linear regression between the HDD and the monthly natural gas bills can be used to separate the amount of gas burned to heat the building from the amount used to produce hot water. For this purpose, the data provided in Figure 3 obtained from the natural gas bills of 2015 to 2016, and Equation (2) was utilized to draw a regression line (Figure 4).

According to this data:

$$
y=11.375 x+1120.6
$$

According to Equation (3), the building base-load due to water heating was $1120.6 \mathrm{kWh}$ per month. Since the mean monthly natural gas consumption amounted to $3637.3 \mathrm{kWh}$, the monthly heating load was $2616.7 \mathrm{kWh}$. It should be noted that the data in this diagram had a correlation coefficient of 0.95 , which was acceptable for 24 data points. 


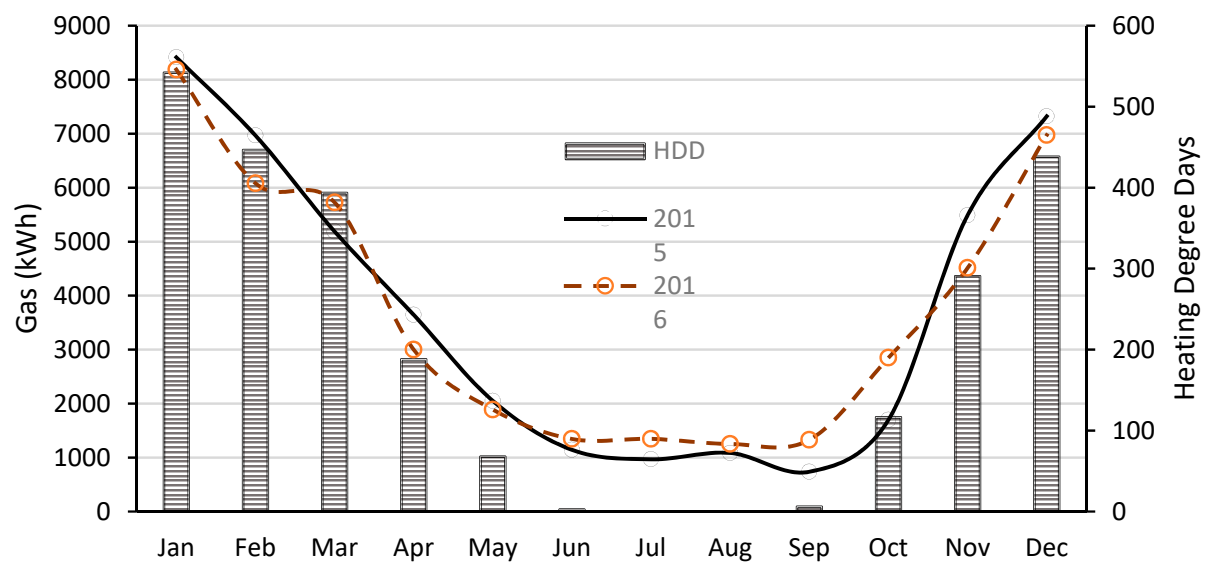

Figure 3. Gas consumption based on heating degree days (HDD).

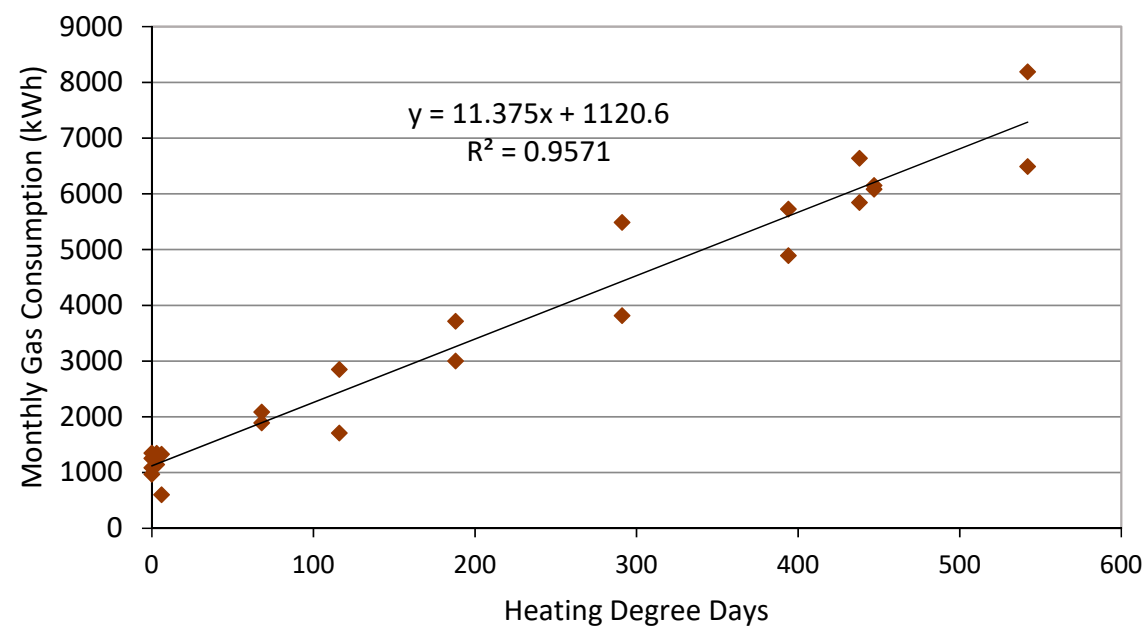

Figure 4. Linear regression between the natural gas consumption and the heating degree days (HDD).

\section{Total Electricity and Natural Gas Consumption}

According to the electricity bills of 2015 to 2016, the building had a mean annual electricity consumption of $2861 \mathrm{kWh}$, of which $416 \mathrm{kWh}$ belonged to cooling and $2445 \mathrm{kWh}$ was related to household appliances and lighting. Table 4 shows that approximately $94 \%$ of energy usage in this building is consumed was the form of natural gas, and of this amount, $69 \%$ and $31 \%$ were consumed for heating and hot water respectively. Electrical energy constituted only $6 \%$ of energy used and of this amount, $85 \%$ was consumed for household appliances and lighting, and 15\% was used for cooling. Notably, despite having a dominant share in total energy consumption, natural gas constituted only $64 \%$ of the annual energy bill. This apparent anomaly is due to the Iranian government subsidization of natural gas in cold regions during cold months, making gas cheaper than electricity [50].

Table 4. Breakdown of the building energy consumption.

\begin{tabular}{cccc}
\hline Fuel Type & Use & $\begin{array}{c}\text { Mean Annual Consumption } \\
\mathbf{( k W h} / \mathbf{m}^{\mathbf{2}} \mathbf{)}\end{array}$ & $\begin{array}{c}\text { Mean Annual Cost } \\
\text { (Rials) }\end{array}$ \\
\hline \multirow{3}{*}{ Gas } & Heating & 243.55 & \\
& Hot water & 108.45 & $2,354,685.50$ \\
& Total & 352 & \\
\hline \multirow{2}{*}{ Electricity } & Cooling & 3.35 & $1,305,000$ \\
& Lighting and appliances & 19.7 & \\
\hline
\end{tabular}




\section{Model}

EnergyPlus V.8.2 was utilized to simulate the building according to the conditions described in Section 1. The infiltration value required for simulation was calculated using a gas detector. In this method, the air ventilation in the building can be obtained by measuring the air changes per hour $(\mathrm{ACH})$, which in turn can be determined based on the time variations of dispersion of an indicator gas. The concentration of the indicator gas at any given time is expressed as:

$$
\mathrm{C}(\mathrm{t})=\mathrm{C}_{0} \cdot \mathrm{e}^{-\mathrm{ACH}}
$$

Or

$$
\mathrm{ACH}=\frac{\dot{\mathrm{V}}}{\mathrm{V}_{\mathrm{bldg}}}=\frac{1}{\mathrm{t}} \cdot \ln \left[\frac{\mathrm{C}_{0}}{\mathrm{C}(\mathrm{t})}\right]
$$

In the above equation, $\dot{V}$ is the volume of air infiltrating into the building in time $t, V_{\text {bldg }}$ is the volume of space into which gas is injected, $C(t)$ is the concentration of the indicator gas in time $t, C_{0}$ is the concentration of the indicator gas in time $t_{0}$, and $t$ denotes the gas sampling time. In this study, we used carbon dioxide as the indicator gas and used the EXTECH SD800 with a precision of 1 ppm to measure the gas concentration in the air. After injecting the carbon dioxide into the building space, recording the air change developments, and entering the data in Equation (5), the air infiltration in winter was calculated as $0.67 \mathrm{ACH}$.

For validation, the heating load obtained for the year 2015 to 2016 using the regression model was compared with the results obtained from the model in the EnergyPlus software (Figure 5). This comparison showed about 3\% mean difference between the building heating load and the simulated results, which was acceptably low given that the climatic files used in the simulation were the averages of a ten-year period.

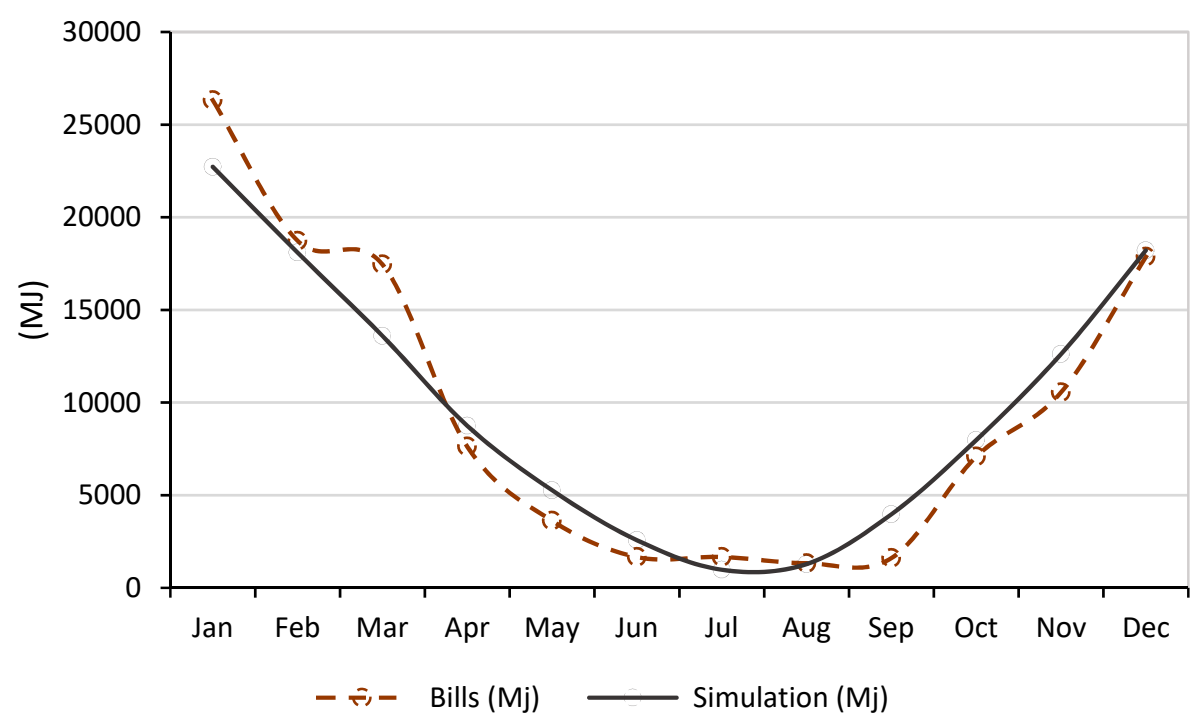

Figure 5. Monthly energy consumption of the experimental and simulated model.

\section{Energy Conservation Opportunities in the Envelope and Windows}

There are several methods to optimize energy consumption in buildings. In the present article, among the sum of available solutions, six strategies have been selected according to the following approaches: (a) being related to the period after the operation of the building; (b) not affecting the performance of the building; (c) having considerable energy efficiency, based on field studies and primary estimations; (d) availability of technical and operational facilities. The first three strategies are related to the optimization of windows, including utilizing low-emissivity coatings on glass surfaces 
to reduce solar radiation, and replacing building windows with differing optimal openings in terms of heat transfer. However, the other three strategies are related to the insulation of the building exterior walls. In this case, based on the measurements and energy consumption reductions, the priorities were first to insulate the roof, then the ceiling and walls, and finally to insulate of all the exterior envelopes.

The total heat transfer coefficient $(\mathrm{U})$ of different components of the building (Table 5) was used to examine the prevalent energy conservation opportunities in the windows and the opaque building envelope, and their associated costs (Table 6). As shown in Table 6, the use of low-emissivity coating with a thermal conductivity coefficient, visible light emission coefficient, and solar reflection coefficients of $5.6 \mathrm{w} / \mathrm{m}^{2} \mathrm{c}, 56 \%, 58 \%$ respectively, caused only a $3.6 \%$ reduction in energy consumption, and exhibited the lowest impact among all solutions. It should, however, be noted that although this method costs about one-quarter of double-glazed windows, its energy conservation impact was just over half of the impact of that solution. The use of relatively expensive triple-glazed windows was shown to reduce consumption by about $9 \%$. It is worth mentioning that a reduction in asymmetric discomfort afforded by Insulated Glazing Units (IGUs) would likely reduce energy consumption further than the model suggests. Despite its high cost, applying polystyrene insulation is a far more effective approach than the modification of windows. For example, applying a $5 \mathrm{~cm}$ insulation over the roof can result in a $22.9 \%$ reduction of the building's annual energy consumption. The application of roof insulation will cost approximately the same as applying a $7 \mathrm{~cm}$ insulation over the northern walls and the floor above the ground level and a $10 \mathrm{~cm}$ insulation over the northern and southern walls, but it is about $5 \%$ more effective. The high effectiveness of roof insulation can be attributed to the upward convection (climbing) of the hot air, which makes the roof a more important intermediary for energy loss than the vertical surfaces (walls). Furthermore, the metal roof construction on this particular building was not the most energy efficient form of construction. Insulating both the roof and the walls or floor would cost less than using triple-glazed windows, but was respectively $14 \%$ and $8.9 \%$ more effective. Insulating the entire envelope would reduce the overall energy consumption by $33 \%$. By applying insulation to the entire envelope, the reference heat transfer coefficient of the building (see Equation (1)) decreased to $241.15 \mathrm{~W} / \mathrm{k}$, resulting in compliance with No. 19 of the Iranian National Building Code.

Table 5. Specifications of the building elements after auditing.

\begin{tabular}{|c|c|c|c|c|c|}
\hline Characteristic/Component & $\mathrm{d}(\mathrm{m})$ & $\lambda(\mathrm{W} / \mathrm{mK})$ & $R\left(m^{2} K / W\right)$ & $\mathrm{U}\left(\mathrm{W} / \mathrm{m}^{2} \mathrm{~K}\right)$ & Detail \\
\hline $\begin{array}{l}\text { Northern wall } \\
\text { Indoor air } \\
\text { Plastic paint } \\
\text { Earth-gypsum plaster } \\
\text { Thermal insulation } \\
\text { Solid bricks } \\
\text { Outdoor air } \\
\text { Total }\end{array}$ & $\begin{array}{l}0.001 \\
0.020 \\
0.070 \\
0.220 \\
0.241\end{array}$ & $\begin{array}{c}1.00 \\
1.10 \\
0.040\end{array}$ & $\begin{array}{c}0.110 \\
0.001 \\
0.018 \\
1.750 \\
0.200 \\
0.06 \\
0.389\end{array}$ & 0.47 & \\
\hline $\begin{array}{c}\text { Southern wall } \\
\text { Indoor air } \\
\text { Plastic paint } \\
\text { Earth-gypsum plaster } \\
\text { Thermal insulation } \\
\text { Solid bricks } \\
\text { Outdoor air } \\
\text { Total }\end{array}$ & $\begin{array}{l}0.001 \\
0.020 \\
0.010 \\
0.110 \\
0.131\end{array}$ & $\begin{array}{l}1.00 \\
1.10 \\
0.04\end{array}$ & $\begin{array}{c}0.110 \\
0.001 \\
0.018 \\
2.5 \\
0.09 \\
0.06 \\
0.279\end{array}$ & 0.36 & \\
\hline
\end{tabular}


Table 5. Cont.

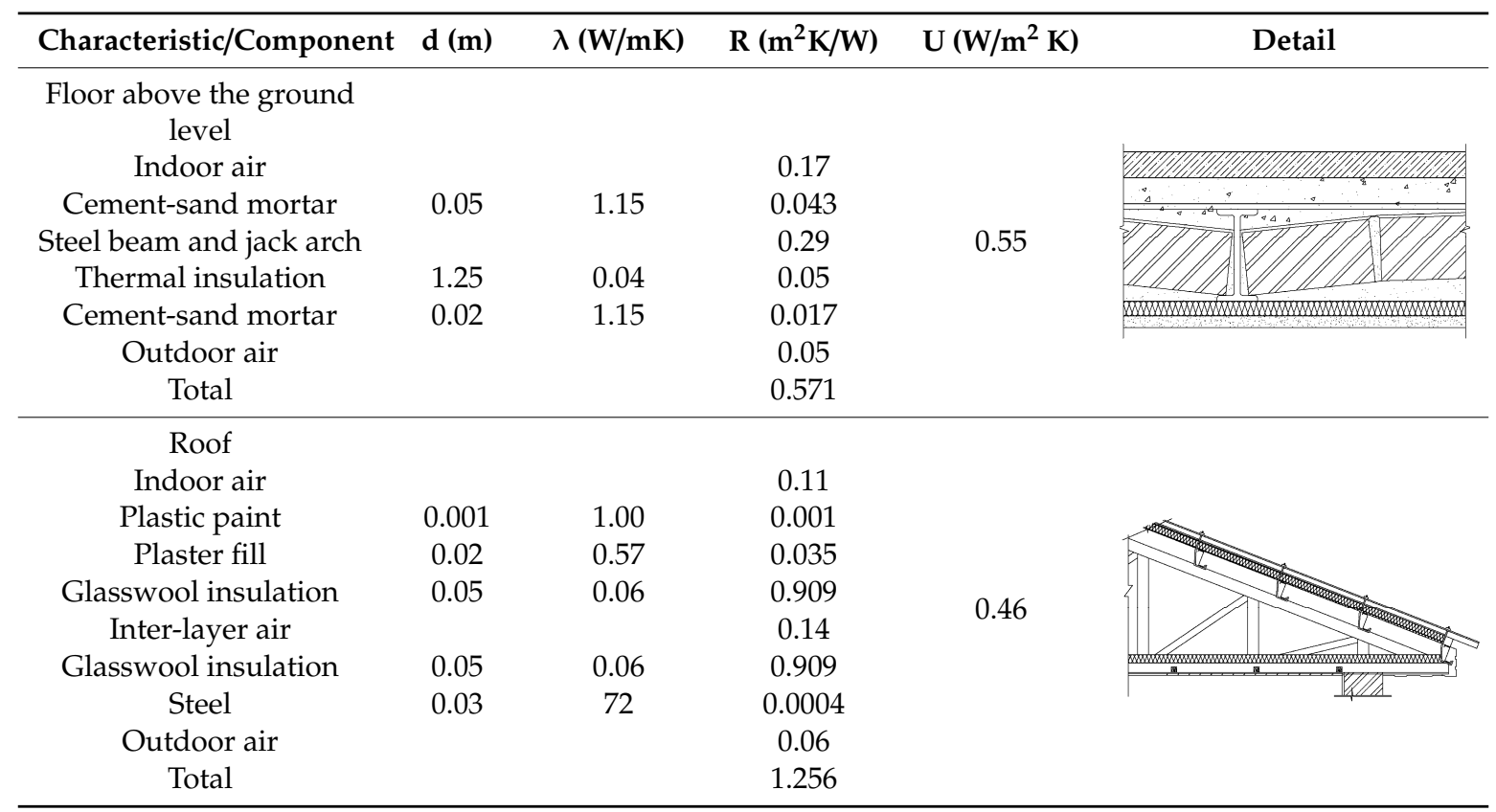

Table 6. Energy conservation scenarios in the envelope and windows.

\begin{tabular}{|c|c|c|c|c|c|c|c|}
\hline & $\begin{array}{l}\text { Baseline } \\
\text { (MJ) }\end{array}$ & $\begin{array}{l}\text { Low Emissivity } \\
\text { Coatings (MJ) }\end{array}$ & $\begin{array}{l}\text { Double-Glazed } \\
\text { Windows (MJ) }\end{array}$ & $\begin{array}{l}\text { Triple-Glazed } \\
\text { Windows } \\
\text { (MJ) }\end{array}$ & $\begin{array}{c}\text { Roof } \\
\text { Insulation } \\
(\mathrm{MJ})\end{array}$ & $\begin{array}{c}\text { Walls + Floor } \\
\text { Insulation (MJ) }\end{array}$ & $\begin{array}{c}\text { Walls + Floor + } \\
\text { Roof Insulation } \\
\text { (MJ) }\end{array}$ \\
\hline January & 22,777 & 21,839 & 21,198 & 20,653 & 18,206 & 19,212 & 16,145 \\
\hline February & 18,172 & 17,482 & 16,979 & 16,529 & 14,399 & 15,248 & 12,714 \\
\hline March & 13,691 & 13,191 & 12,865 & 12,510 & 10,687 & 11,354 & 9325 \\
\hline April & 8849 & 8525 & 8358 & 8118 & 6769 & 7217 & 5807 \\
\hline May & 5404 & 5210 & 5129 & 4965 & 3964 & 4269 & 3299 \\
\hline July & 1075 & 1015 & 1002 & 947 & 606 & 725 & 441 \\
\hline August & 1385 & 1314 & 1299 & 1230 & 789 & 936 & 562 \\
\hline September & 4116 & 4015 & 3943 & 3786 & 2811 & 3108 & 2253 \\
\hline October & 8090 & 7836 & 7631 & 7383 & 6041 & 6492 & 5104 \\
\hline November & 12,690 & 12,231 & 11,884 & 11,543 & 9868 & 10,492 & 8583 \\
\hline December & 18,282 & 17,618 & 17,088 & 16,619 & 14,396 & 15,267 & 12,652 \\
\hline \multicolumn{2}{|c|}{ Cost (IRR) } & $5,480,000$ & $21,920,000$ & $36,168,000$ & $28,662,000$ & $28,500,000$ & $57,162,000$ \\
\hline
\end{tabular}

\section{Energy Optimization Scenarios}

In calculating gas consumption, four factors are taken into consideration: (a) the climate zone where a building is located; (b) the consumption season, divided into two warm and cold seasons; (c) the building functionality; (d) the consumption rate, which increases based on the block tariff [51]. Given the complexity of existing relationships and different assumptions for calculating the final price, in the present paper, the price per cubic meter of gas was calculated by dividing the bill amounts by consumption (in cubic meters) for the selected sample. In countries such as Iran, subsidies are granted to the energy sector based on the government's energy policy. However, the efforts of different governments over time have been to gradually reduce subsidies and allocate them directly to impoverished people, but experience has shown that the consequent rise in energy carrier prices has created a severe inflationary impact on the country's economy, and the cost of transportation and the price of other commodities have also been heavily influenced. Therefore, realization of increased energy carrier rates is always carried out with extreme caution and low haste. For example, based on gas bills in April 2019, the price per cubic meter of gas for the building was set at 1597 Rials 
(approximately $\$ 0.012$ ), while the global price of gas at the Henry Hub market was $\$ 0.092$ per cubic meter [52]. It is important to note that the price of the Henry Hub market is the industry base price, and in many advanced countries, further costs are added to this price. For example, for this month, the average gas price for home use in the US was $\$ 0.31$ [53].

In light of the discussion outlined above, the initial costs required for each of the solutions of the previous section have been calculated. By using six of the previous solutions in this section, the computations of energy saving solutions in the three categories of low-cost, medium-cost and high-cost scenarios will be shown in order to compare the initial investment and payback periods. The results are summarized in Table 7 . In the first and second columns of this table, each of the three scenarios and related strategies is presented. In the third to fifth columns, the annual energy consumption of the building, if utilized by this scenario, is expressed in terms of savings and percentages.

The sixth column shows annual building energy reductions. As discussed earlier, considering the complexity of the gas price calculation, such as price variations for different seasons and the increasing block tariff, in order to calculate the effect of differing scenarios on the final cost first, the results of monthly cuts in accordance with the gas bills were extracted, and then the effect of the decreases in energy consumption in each period was calculated separately; finally it's the total sum was calculated for one year. Lastly, in the final column, the return period for each scenario is shown. Simple payback time method has been used to calculate the return period, which is the amount of initial capital investment divided by the annual profits (here the amount of bills is reduced).

As illustrated in Table 7, in Scenario 1, approximately 7 million Rials investment in the low-cost solution consisting of roof insulation, draught proofing, and low-emissivity coatings on windows, will reduce the building energy consumption by about 21\%. Based on the energy prices of 2017 [54], such investment will have a payback period of about 11 years. Scenario 2 includes roof insulation as well as other medium-cost solutions such as insulation of outer walls and the floor above the ground level and the use of double-glazed windows, would mean a $43 \%$ reduction in building energy consumption, which is equivalent to an annual cost saving of about 1,361,500 Rials. The payback period of such investments is more than 40 years. Scenario 3 is similar to the previous scenario except that double-glazed windows are replaced with triple-glazed windows (with lower heat transfer coefficients), and that $75 \%$ of hot water is supplied by two solar water heaters (Optima, Polar Co. [55]) with an area of $4 \mathrm{~m}^{2}$ and efficiency of $40 \%$. Since Nahavand has a solar irradiance of about $5 \mathrm{kWh} / \mathrm{m}^{2}$ per day and this setup will save about $2920 \mathrm{kWh}$ of energy, which is equivalent to $282 \mathrm{~m}^{3}$ of natural gas. Thus, the total energy conservation of Scenario 3 will be $63,366 \mathrm{MJ}$, which is equivalent to $54 \%$ of the building's total heating load. The downside of this investment scenario is its 55-year payback period, which given the 50-year average life of buildings, makes this solution impractical. In general, with the current prices of energy and building materials, even the low-cost solution will have a 10-year payback period; thus, the solutions proving higher energy efficiencies are not economically justified, at least not in the present time. 
Table 7. Energy consumption at present and in each optimization scenario.

\begin{tabular}{|c|c|c|c|c|c|c|c|}
\hline Scenario & Solution & $\begin{array}{c}\text { Total Energy } \\
\text { Consumption } \\
\text { (MJ) }\end{array}$ & $\begin{array}{l}\text { Energy Saving } \\
\text { Relative to } \\
\text { Baseline (MJ) }\end{array}$ & $\begin{array}{c}\text { Energy Saving } \\
\text { Percentage }\end{array}$ & $\begin{array}{l}\text { Initial } \\
\text { Investment } \\
\text { (Rials) }\end{array}$ & $\begin{array}{c}\text { Annual } \\
\text { Saving (Rials) }\end{array}$ & $\begin{array}{c}\text { Payback } \\
\text { Period (Year) }\end{array}$ \\
\hline $\begin{array}{l}\text { Low-cost } \\
\text { scenario }\end{array}$ & $\begin{array}{ll}\text { - } & \text { Use of low-emissivity glass } \\
\text { - } & \text { Use of draught proofing } \\
\text { - } & \text { Insulation of the roof }\end{array}$ & 92,777 & 24,471 & 20.8 & $7,063,400$ & 656,050 & 10.7 \\
\hline $\begin{array}{l}\text { Medium-cost } \\
\text { scenario }\end{array}$ & $\begin{array}{ll}- & \text { Insulation of the roof } \\
- & \text { Insulation of the outer walls } \\
- & \text { Insulation of the floor above } \\
\text { the ground level } \\
\text { - } & \text { Use of } \\
\text { double-glazed windows }\end{array}$ & 66,464 & 50,784 & 43.3 & $5,501,540$ & $1,361,500$ & 40 \\
\hline $\begin{array}{l}\text { High-cost } \\
\text { scenario }\end{array}$ & $\begin{array}{ll}- & \text { Insulation of the roof } \\
- & \text { Insulation of the outer walls } \\
- & \text { Insulation of the floor above } \\
\text { the ground level } \\
\text { - }\end{array}$ & 53,881 & 63,366 & 54 & $9,466,430$ & $1,699,150$ & 57.6 \\
\hline
\end{tabular}




\section{Conclusions}

In this study, an energy audit was conducted on a residential building typical to the cold regions of Iran. The analysis of this building showed that the specifications and materials of the building envelope failed to meet the national standards of Iran. An examination of the building's energy bills revealed that natural gas consumption is responsible for $94 \%$ of the total energy used in this building, and of this amount, approximately $70 \%$ is being used for heating. Electricity accounts for only $6 \%$ of the total energy due to measures such as the utilization of energy-saving light bulbs and relatively low cooling loads (because of the cold climate). However, due to the high subsidization of natural gas in Iran's cold regions and relatively higher price of electricity, about $36 \%$ of the total energy bill is related to electricity. This investigation into improving energy efficiency of the building envelope showed that insulating the opaque elements is more cost-effective and results in greater energy saving than modifying the windows. For example, insulating the roof, walls and floor was found to be three times more effective than using double-glazed windows, without any significant cost difference. The most cost-effective solution was found to be the insulation of the roof, which alone reduces energy consumption by about $30 \%$. In contrast, the best window optimization solution, that is, the use of triple-glazed windows, results in about $9 \%$ energy conservation but costs $20 \%$ more than insulating the roof. The low cost, medium-cost, and high-cost optimizations scenarios considered were found to decrease the annual energy consumption by respectively $20.8 \%, 43.3 \%$, and $54 \%$, but had respective payback periods of 10.7, 40, and 57.6 years. These long payback periods indicate that with the current prices of energy and materials, the use of reviewed energy conservation strategies and technologies such as solar panels are not economically justified from the Iranian consumer perspective.

Author Contributions: Writing, data collection, and simulation, E.S. and S.S; numerical analysis, R.H. and F.A; literature review and revision, R.F.

Funding: This research received no external funding.

Conflicts of Interest: The authors declare no conflict of interest.

\section{Nomenclature}

$\hat{\mathrm{H}} \quad$ The reference heat transfer coefficient of the building $(\mathrm{w} / \mathrm{k})$

$A_{W} \quad$ The total area of the walls adjacent to the outdoor space $\left(\mathrm{m}^{2}\right)$

$\hat{U}_{W} \quad$ The reference surface heat transfer coefficient of the walls $\left(\mathrm{W} / \mathrm{m}^{2} \mathrm{~K}\right)$

$A_{R} \quad$ The total area of the flat or sloped roofs adjacent to the outdoor space $\left(\mathrm{m}^{2}\right)$

$\hat{\mathrm{U}}_{\mathrm{R}} \quad$ The reference surface heat transfer coefficient of the flat or sloped roofs $\left(\mathrm{W} / \mathrm{m}^{2} \mathrm{~K}\right)$

$\mathrm{A}_{\mathrm{F}} \quad$ The total area of the floor in contact with the outside air $\left(\mathrm{m}^{2}\right)$

$\hat{\mathrm{U}}_{\mathrm{F}} \quad$ The reference surface heat transfer coefficient of the floor in contact with the outdoor air $\left(\mathrm{W} / \mathrm{m}^{2} \mathrm{~K}\right)$

$\mathrm{P} \quad$ The total perimeter of the floor in contact with soil, adjacent to the outdoor space (m)

$\hat{\mathrm{U}}_{\mathrm{P}} \quad$ The reference linear heat transfer coefficient of the floor in contact with soil $\left(\mathrm{W} / \mathrm{m}^{2} \mathrm{~K}\right)$

$\mathrm{A}_{\mathrm{G}} \quad$ The total area of the windows opening to the outdoor space $\left(\mathrm{m}^{2}\right)$

$\hat{U}_{\mathrm{G}} \quad$ The reference surface heat transfer coefficient of the windows and their frames $\left(\mathrm{W} / \mathrm{m}^{2} \mathrm{~K}\right)$

$A_{D} \quad$ The total area of the doors opening to the outdoor space $\left(\mathrm{m}^{2}\right)$

$\hat{U}_{D} \quad$ The reference surface heat transfer coefficient of the doors $\left(\mathrm{W} / \mathrm{m}^{2} \mathrm{~K}\right)$

$\mathrm{A}_{W B} \quad$ The total area of the barriers in contact with uncontrolled spaces $\left(\mathrm{m}^{2}\right)$

$\hat{U}_{W B} \quad$ The reference surface heat transfer coefficient of the barriers in contact with uncontrolled spaces $\left(\mathrm{W} / \mathrm{m}^{2} \mathrm{~K}\right)$

\section{References}

1. IPCC. Synthesis Report. Contribution of Working Groups I, II and III to the Fourth Assessment Report of the Intergovernmental Panel on Climate Change; IPCC: Geneva, Switzerland, 2007.

2. Schellnhuber, H.J. Global warming: Stop worrying, start panicking? Proc. Natl. Acad. Sci. USA 2008, 105, 14239-14240. [CrossRef] [PubMed]

3. Saidur, R.; Masjuki, H.; Jamaluddin, M.; Ahmed, S. Energy and associated greenhouse gas emissions from household appliances in Malaysia. Energy Policy 2007, 35, 1648-1657. [CrossRef] 
4. Hossain, M.; Rahman, M.Z.; Selim, M.M. Energy Audit and Base Case Simulation of Ryerson University Buildings. ASHRAE Trans. 2015, 121, 84-98.

5. Omer, A.M. Renewable building energy systems and passive human comfort solutions. Renew. Sustain. Energy Rev. 2008, 12, 1562-1587. [CrossRef]

6. Jayamaha, D.L. Energy-Efficient Building Systems; Mcgraw-Hill Publishing Company: New York, NY, USA, 2007.

7. Pacheco-Torgal, F.; Cabeza, L.; Mistretta, M.; Kaklauskas, A.; Granqvist, C. Nearly Zero Energy Building Refurbishment-A Multidisciplinary Approach; Springer: London, UK, 2013.

8. Langston, C.; Wong, F.K.; Hui, E.C.; Shen, L.-Y.; Hui, E.C.M. Strategic assessment of building adaptive reuse opportunities in Hong Kong. Build. Environ. 2008, 43, 1709-1718. [CrossRef]

9. Ürge-Vorsatz, D.; Novikova, A. Potentials and costs of carbon dioxide mitigation in the world's buildings. Energy Policy 2008, 36, 642-661. [CrossRef]

10. Sunikka, M.; Boon, C. Environmental policies and efforts in social housing: The Netherlands. Build. Res. Inf. 2003, 31, 1-12. [CrossRef]

11. Capehart, B.L.; Turner, W.C.; Kennedy, W.J. Guide to Energy Management; Fairmont Press, Inc.: Lilburn, GA, USA, 2006.

12. Lee, S.E.; Haji-Sapar, M.; Haji-Sapar, M. Establishment of energy management tools for facilities managers in the tropical region. Facilities 2005, 23, 416-425.

13. Sterling, E.M.; Collett, C.; Turner, S.; Downing, C. Commissioning to avoid indoor air quality problems. ASHRAE J. 1992, 34.

14. Rahman, M. Building Energy Conservation and Indoor Air Quality Assessment in a Subtropical Climate. Ph.D. Thesis, Central Queensland University, Faculty of Sciences, Engineering and Health, Queensland, Australia, 2008.

15. NSAI Standards. E.C.f. CEN-EN 16247-1 in ENERGY AUDITS-PART 1: General Requirements; NSAI Standards: Dublin, Ireland, 2012.

16. Dall'O', G.; Speccher, A.; Bruni, E. The Green Energy Audit, a new procedure for the sustainable auditing of existing buildings integrated with the LEED Protocols. Sustain. Cities Soc. 2012, 3, 54-65. [CrossRef]

17. ASHRAE. ANSI/ASHRAE Standard 100-2006. In Energy Conservation in Existing Building; ASHRAE: Atlanta, GA, USA, 2006.

18. Barelli, L.; Bidini, G. Development of an energetic diagnosis method for the buildings: Example of the Perugia University. Energy Build. 2004, 36, 81-87. [CrossRef]

19. Recalcati, R.; Dall'O, G. Procedure for Buildings Energetic Certification; Punto Energia: Brescia, Italy, 1998.

20. EMSD. Guidelines on Energy Audit; Electrical and Mechanical Services Department: The Government of the Hong Kong Special Administrative Region, Hong Kong, 2012.

21. Handbook, A.F. American Society of Heating, Refrigerating and Air-Conditioning Engineers; ASHRAE Inc.: Atlanta, GA, USA, 2009.

22. Doty, S.; Turner, W.C. Energy Management Handbook, 8th ed; Fairmont Press, Inc.: Lilburn, GA, USA, 2013.

23. Eskin, N.; Türkmen, H. Analysis of annual heating and cooling energy requirements for office buildings in different climates in Turkey. Energy Build. 2008, 40, 763-773. [CrossRef]

24. Claridge, D.; Haberl, J.S.; Turner, D.; O’Neal, D.; Heffington, W.; Tombari, C.; Roberts, M.; Jaeger, S. Improving energy conservation retrofits with measured savings. ASHRAE J. 1991, 33.

25. Rahman, M.M.; Rasul, M.; Khan, M. Energy conservation measures in an institutional building in sub-tropical climate in Australia. Appl. Energy 2010, 87, 2994-3004. [CrossRef]

26. Li, J.S. A study of energy performance and efficiency improvement procedures of Government Offices in Hong Kong Special Administrative Region. Energy Build. 2008, 40, 1872-1875. [CrossRef]

27. Iqbal, I.; Al-Homoud, M.S. Parametric analysis of alternative energy conservation measures in an office building in hot and humid climate. Build. Environ. 2007, 42, 2166-2177. [CrossRef]

28. Escrivá-Escrivá, G.; Álvarez-Bel, C.; Valencia-Salazar, I. Method for modelling space conditioning aggregated daily load curves: Application to a university building. Energy Build. 2010, 42, 1275-1282. [CrossRef]

29. Mills, E.; Friedman, H.; Powell, T.; Bourassa, N.; Claridge, D.; Haasl, T.; Piette, M.N. The Cost-Effectiveness of Commercial-Buildings Commissioning; Lawrence Berkeley National Laboratory Report No. 56637. LBNL-56637; Lawrence Berkeley National Laboratory: Alameda County, CA, USA, 2004.

30. Yu, P.C.; Chow, W.K. A discussion on potentials of saving energy use for commercial buildings in Hong Kong. Energy 2007, 32, 83-94. [CrossRef] 
31. Ruiz, M.; Romero, E. Energy saving in the conventional design of a Spanish house using thermal simulation. Energy Build. 2011, 43, 3226-3235. [CrossRef]

32. Asadi, E.; Da Silva, M.G.; Antunes, C.H.; Dias, L.; Da Silva, M.C.G. Multi-objective optimization for building retrofit strategies: A model and an application. Energy Build. 2012, 44, 81-87. [CrossRef]

33. Zhu, Y. Applying computer-based simulation to energy auditing: A case study. Energy Build. 2006, 38, 421-428. [CrossRef]

34. Ascione, F.; Bianco, N.; de Masi, R.F.; Rossi, F.D.; Vanoli, G.P. Energy refurbishment of existing buildings through the use of phase change materials: Energy savings and indoor comfort in the cooling season. Appl. Energy 2014, 113, 990-1007. [CrossRef]

35. Solgi, E.; Fayaz, R.; Kari, B.M. Cooling load reduction in office buildings of hot-arid climate, combining phase change materials and night purge ventilation. Renew. Energy 2016, 85, 725-731. [CrossRef]

36. Solgi, E.; Kari, B.M.; Fayaz, R.; Hoseini, B.; Taheri, H. Enhancing the Performance of Night Ventilation Systems in Office Buildings Using Phase Change Materials, Case Study in Yazd. Arman. Arch. Urban Dev. 2017, 9, 53-62.

37. Solgi, E.; Hamedani, Z.; Fernando, R.; Skates, H.; Orji, N.E. A literature review of night ventilation strategies in buildings. Energy Build. 2018, 173, 337-352. [CrossRef]

38. Solgi, E.; Kari, B.M.; Fayaz, R.; Taheri, H. The impact of phase change materials assisted night purge ventilation on the indoor thermal conditions of office buildings in hot-arid climates. Energy Build. 2017, 150, 488-497. [CrossRef]

39. Solgi, E.; Hamedani, Z.; Fernando, R.; Kari, B.M.; Skates, H. A parametric study of phase change material behaviour when used with night ventilation in different climatic zones. Build. Environ. 2019, 147, 327-336. [CrossRef]

40. Fazlikhani, F.; Goudarzi, H.; Solgi, E. Numerical analysis of the efficiency of earth to air heat exchange systems in cold and hot-arid climates. Energy Convers. Manag. 2017, 148, 78-89. [CrossRef]

41. Hashemi, N.; Fayaz, R.; Sarshar, M. Thermal behaviour of a ventilated double skin facade in hot arid climate. Energy Build. 2010, 42, 1823-1832. [CrossRef]

42. Hamedani, Z. Smart Housing: A Tool for Building Intelligent Environment. Master's Thesis, Architecture and Urban Planning, University of Science and Technology, Tehran, Iran, 2011.

43. Chaharmahal \& Bakhtiari Meteorogical Administration. Available online: http://www.chaharmahalmet.ir/ (accessed on 14 April 2017).

44. Kottek, M.; Grieser, J.; Beck, C.; Rudolf, B.; Rubel, F. World Map of the Köppen-Geiger climate classification updated. Meteorol. Z. 2006, 15, 259-263. [CrossRef]

45. Code No. 19: Energy Efficiency. In Bureau for Compiling and Promoting National Regulations for Buildings; Ministry of Housing and Urbanism: Tehran, Iran, 2011; p. 150.

46. Krarti, M. Energy Audit of Building Systems: An Engineering Approach; CRC Press: Boca Raton, FL, USA, 2016.

47. Fels, M. The Princeton Scorekeeping Method (PRISM). Percentage of Naturally Ventilated Area of Three Buildings. (Source: DESCO, DPDC and Field Survey); Special Issue Devoted to Measuring Energy Savings: Princeton, NJ, USA, 1986.

48. Rasmussen, B.P.; Kreider, J.F.; Claridge, D.E.; Culp, C.H. Heating, Ventilating, and Air-Conditioning Control Systems. In Energy Management and Conservation Handbook; CRC Press: Boca Raton, FL, USA, 2016; pp. 123-178.

49. Kissock, J.K.; Reddy, T.A.; Claridge, D.E. Ambient-Temperature Regression Analysis for Estimating Retrofit Savings in Commercial Buildings. J. Sol. Energy Eng. 1998, 120, 168-176. [CrossRef]

50. Ministry of Energy. Available online: http://www.moe.gov.ir/ (accessed on 22 March 2017).

51. Solgi, E.; Memarian, S.; Moud, G.N. Financial viability of PCMs in countries with low energy cost: A case study of different climates in Iran. Energy Build. 2018, 173, 128-137. [CrossRef]

52. Macrotrends. Available online: https://www.macrotrends.net/2478/natural-gas-prices-historical-chart (accessed on 29 July 2019).

53. U.S. Energy Information Adminstration. Available online: https://www.eia.gov/ (accessed on 31 July 2019). 
54. National Iranian Gas Company. Available online: http://www.nigc.ir/ (accessed on 21 March 2017).

55. Polarstore. Available online: http://polarstore.ir/ (accessed on 29 July 2019).

(C) 2019 by the authors. Licensee MDPI, Basel, Switzerland. This article is an open access article distributed under the terms and conditions of the Creative Commons Attribution (CC BY) license (http://creativecommons.org/licenses/by/4.0/). 